\title{
RECENZJE
}

\section{DobromiŁa Nowicka, Zniestawienie w prawie rzymskim, Wrocław 2013, (Uniwersytet Wrocławski, Prawnicza i Ekonomiczna Biblioteka Cyfrowa, ss. 334).}

Tytuł książki wzbudza pewne zaniepokojenie, ponieważ w prawie rzymskim zniesławienie jako osobna instytucja prawna nie występuje. Odpowiednikiem zniesławiania w języku łacińskim jest przede wszystkim infamare, infamatio i infamia, podczas gdy objęta książką problematyka odnosi się do rzymskiej iniurii (iniuria) Ta z kolei oznacza choćby podręcznikowo delikt rzymskiego prawa cywilnego, który w takim ujęciu również wymyka się z opracowania. Z tych trudności Autorka zdaje sobie dobrze sprawę i już we „Wstępie” (s. 11) doprecyzowuje przedmiot i zakres badań. Poruszając się między zachowaniami ukierunkowanymi ad infamandam alicuius oraz zastosowaniami iniurii zawęża rozumienie pojęcia zniesławienia do ustnych i pisemnych form naruszenia dobrego imienia lub jeszcze dokładniej: „Zniesławienie, będące przedmiotem niniejszej pracy, rozumiane zatem będzie jako zamach na dobre imię innej osoby za pomocą działań werbalnych" (s. 14). Tak też konkretyzuje zniesławienie np. w tytule rozdziału I: „Kształtowanie się ochrony dobrego imienia w rzymskich regulacjach prawnych" oraz w Zakończeniu (s. 293), gdzie już bez wyrażania wątpliwości posługuje się określeniem „ochrony dobrego imienia".

Takie określenie tematu badań można uznać za zasadne, chociaż nie bez zastrzeżeń. Tak np. Autorka uzasadnia swój wybór m. in. nawiązaniem ,do przeważającego rozumienia pojęcia zniesławienia w prawie polskim" (s. 13), chociaż od razu (s. 14) zastrzega się niezbyt konsekwentnie, że „Nie jest jednak moim celem przeprowadzenie analizy czynu określanego mianem zniesławienia czy precyzyjniej - 
pomówienia - w prawie polskim ani też zestawienie go z rzymskim pojęciem takiego zachowania". To może nienajlepsza postawa badawcza, ponieważ odniesienie się do prawa polskiego pozwoliłoby np. na zauważenie - obok zniesławienia i pomówienia - również osobno normowanego znieważenia. Pewną podpowiedź można było znaleźć już w mojej książce „Prawo i obyczaje w starożytnym Rzymie”, zresztą przez Autorkę cytowanej (por. choćby s. 23), gdzie zamieściłem tytuł „Zniesławienie i zniewaga”, odnoszący się do treści rzymskiej iniurii, która - w moim przekonaniu - najbardziej odpowiada współczesnym pojęciom właśnie zniesławienia i znieważenia. Dodać można, że pominięte programowo przez Autorkę odniesienie do współczesności zyskałoby niewątpliwie duże uznanie w niektórych kręgach romanistycznych w Polsce.

Całość ujęła D. Nowicka w trzy rozdziały: I. to wspomniane już „Kształtowanie się ochrony dobrego imienia w rzymskich regulacjach prawnych”(s. 26-104), II. „Formy zachowań karalnych” (105-212) oraz III. „Ochrona procesowa” (s. 213-292). Ponadto obszerny, merytoryczny „Wstęp” (s. 11-25) oraz treściwe „Zakończenie” (293-301). Jeśli dodać wykazy skrótów, wykazy wykorzystanych źródeł oraz bibliografii, to otrzymujemy dobrze skonstruowaną całość, spełniającą wymagania warsztatowe. W obrębie wymienionych rozdziałów Autorka porusza liczne szczegółowe zagadnienia, ale zawsze dobrze trzymające się określonej $\mathrm{w}$ danym rozdziale oraz w całości linii badawczej. Dla rozdziału I jest nią rozwój historyczny uregulowań rzymskich, odnoszących się do ochrony dobrego imienia (zniesławienia), w rozdziale II wydobywa różne formy zachowań, które podlegały karalności z powodu naruszenia dobrego imienia osoby, zaś rozdział III to problematyka procesowa, a więc środki procesowe oraz odrębności postępowania w sprawach o zniesławienie. Dodać trzeba, że Autorka, co zaznacza już we „Wstępie”(s. 14), obejmuje swoimi badaniami i rozważaniami cały okres rozwoju prawa rzymskiego od ustawy XII Tablic do kodyfikacji justyniańskiej z odrębnym zaznaczaniem uregulowań prawa poklasycznego, co nie zawsze się w monografiach z zakresu prawa rzymskiego zdarza, a zawsze stanowi cenne uzupełnienie między prawem klasycznym a justyniańskim. 
Zgodnie ze wstępną zapowiedzią w rozdziale I prowadzi D. Nowicka przegląd regulacji, odnoszących się do ochrony dobrego imienia na różnych etapach rozwoju prawa rzymskiego. Zaczyna od ustawy XII tablic, zawierającej normę tab. 8,4: Si iniuriam alteri faxsit, viginti quinque poenae sunto. Odnosiła się ona do przypadków o lżejszej wadze (G. 3,223: propter ceteras iniurias - s. 28-30), które Autorka wyłącza z dalszych rozważań (s. 35), ponieważ miały one charakter naruszenia nietykalności cielesnej, a nie słownego zniesławienia. Zauważyć przy tym można, że spoliczkowanie, uznane za typowy przykład lżejszej iniurii (Gell. 20,1,12-13), jest również klasycznym przykładem znieważenia. Po szerszej analizie wyłącza ponadto D. Nowicka z zakresu zniesławienia słowne nawet zniewagi, ale o charakterze magicznym (malum carmen incantare; occentare; carmen condere oraz czynne flagitium - s. 35-58), ponieważ „Penalizacja zniesławień i zniewag słownych na etapie ewolucji społecznej charakterystycznym dla poziomu rozwoju Rzymu w czasie powstawania ustawy nie znajduje uzasadnienia ani w istnieniu koncepcji osobowości, która pojawiła się znacznie później, ani też w konieczności zapewnienia ochrony przed zniesławiającą twórczością poetów, będącą wówczas w stadium inicjalnym” (s. 53). W, ,inicjalnej” części omawianej monografii stwierdzenie to wydaje się zbyt skrótowe i ogólnikowe, ale znów można je uznać co do zasady.

Drugi etap stanowią edykty pretorskie okresu przedklasycznego (s. 59-80). Chodzi o edictum generale de iniuriis aestimandis, e. de convicio, e. de adtemptata pudicitia oraz e. ne quid infamandi causa fiat. Co do pierwszego słusznie D. Nowicka zauważa (s. 60-64), że celem jego była zmiana dotychczasowych sztywnych stawek za iniuria według ustawy XII tablic. Nie wprowadzał natomiast rozróżnienia między naruszeniem nietykalności cielesnej a ochroną dobrego imienia. Następny edykt już stanowił w omawianym zakresie znaczny postęp, ponieważ regulował odpowiedzialność za adversus bonos mores convicium facere, co Autorka rozumie jako ustną formę ataku na osobowość drugiego człowieka, dokonywaną podniesionym głosem lub w grupie (s. 65), chociaż dostrzega w nim przede wszystkim pojawienie się odrębnej ochrony procesowej za wymienione działania 
(s. 66). Podobnie, jak stwierdza na s. 66, postrzegane były czyny objęte edyktem de adtemptata pudicitia. Tu dopuszcza już powiązania edyktu z ochroną skromności i naruszeniem dobrego imienia. Przelotnie zaznacza w tym kontekście przesłankę adversus bonos mores w odniesieniu do działań określanych jako appelare i adsectare (s. 68), o czym zapomniała wcześniej przy convicium (adversus bonos mores), a znaczenie dobrych obyczajów w tym kontekście zasługiwało na znacznie większe zainteresowanie (patrz też niżej). Edykt ne quid infamandi causa fiat stanowił, zdaniem Autorki (s. 80) unormowanie odrębnego stanu faktycznego, niezależnego od convicium, pudicitia czy iniuria. W sumie, te właśnie trzy specjalne edykty, tworzyły podstawy ochrony przed „zniesławieniem niecielesnym” (s. 81). Z kolei, uchwały senatu (senatus consulta) okresu klasycznego, znane tylko z pośrednich i niejednoznacznych przekazów, ujawniają kwestię zniesławień pisemnych (np. libelli famosi), m. in. w związku z crimen laesae maiestatis. To trudna badawczo problematyka, w omawianej monografii przedstawiona w wystarczającym zakresie, chociaż przy dość rozbudowanej literaturze, dotyczącej obrazy majestatu w prawie rzymskim, mogłaby stanowić temat do osobnego i pogłębionego opracowania. Rozdział I kończą uwagi odnoszące się do prawa poklasycznego oraz wnioski końcowe. Zaznacza w nich Autorka m. in. znaczenie wymienionych edyktów jeszcze dla prawa justyniańskiego, chociaż zanikło ono wraz z rozbudową deliktu iniurii. Podobnie wchłonięte zostały w rozmaitych skrótach i modyfikacjach rozwiązania przekazane w Kodeksie Teodozjańskim.

Rozdział II to formy zachowań karalnych. Powraca tu D. Nowicka do adversus bonos mores convicium facere jako działań skierowanym przeciw reputacji lub godności innej osoby, tym razem z większym podkreśleniem znaczenia przesłanki uchybienia dobrym obyczajom (s. 119). Podobnie szerokie i gruntowne omówienie znalazło adversus bonos mores appelare (s. 126-137) z uwzględnieniem prawa poklasycznego. Z punktu tematyki badawczej monografii na pierwsze miejsce wysuwa się oczywiście infamandi causa factum rozpatrywane w zakresie słownych form naruszenia dobrego imienia. To ten edykt wprowadził już jednoznaczną karalność każdego zachowania, 
ukierunkowanego na zniesławienie innej osoby, przy czym czyn zniesławiający mógł się przejawiać „,W niemal dowolny sposób” (s. 137). To w całości interesujący podrozdział, zwłaszcza w połączeniu z obszernym i szczegółowym II.4: Libelli famosi oraz inne formy zniesławienia pisemnego (s. 153-184) oraz II.5: Calumnia i falsa delatio (s. 184-210). W sumie rozdział najlepiej oddający tytułową problematykę zniesławienia w prawie rzymskim.

Ochrona procesowa (rozdział III) jawi się jako konieczne dopełnienie poprzednich treści monografii. Tytuł jest może zbyt skrótowy, nie wskazuje bowiem, kto kogo i przed czym miałby środkami procesowymi chronić, zwłaszcza że przedstawia tu Autorka zwykłe środki ochrony procesowej (actio iniuriarum aestimatoria jako a. in bonum et aequum concepta - s. 216), odrębności postępowania w sprawach o pisemne formy zniesławienia oraz zbieg skarg z tytułu zniesławienia. Na pozytywne zauważenie zasługuje jednak najważniejsze rozróżnienie między civiliter agere i criminaliter agere, z czasem bowiem do deliktowej actio iniuriarum dołączyła kryminalna represja extra ordinem, która stała się charakterystyczna dla okresu poklasycznego. „Równowagę i możliwość wyboru między obiema drogami postępowania przywróciło dopiero postępowanie justyniańskie" (s. 297). W treściwym „Zakończeniu” powraca D. Nowicka m. in. do osobnego reżimu „pewnych rodzajów zniesławień pisemnych” (s. 297) W ten sposób odchodzi nieco od wstępnego założenia, że "Zniesławienie, będące przedmiotem niniejszej pracy, rozumiane zatem będzie jako zamach na dobre imię innej osoby za pomocą działań werbalnych" (s. 14). Trafnie jednak (i samokrytycznie) oświadcza, że „Mimo próby rzetelnego przedstawienia zachowań zaliczanych przeze mnie do zniesławiających niemożność osadzenia każdego z nich w szerszym kontekście, spowodowana koniecznością zachowania spójności głównej linii rozważań, stanęła na drodze wyczerpującym studiom nad tymi zagadnieniami” (s. 301). Dodaje do tego kilka innych jeszcze usprawiedliwień, może jednak niepotrzebnie, ponieważ wykazała w swojej rozprawie wysokie umiejętności badawcze oraz bardzo dobre rozeznanie $\mathrm{w}$ analizowanej problematyce. Pewne wątpliwości i świadomość możliwych niedoskonałości wynikać mogą z trudnego 
pomysłu na przedstawienie zagadnień, które ze swej istoty nie tworzyły wyodrębnionej i spójnej całości, ponieważ - jak od początku wiemy - w prawie rzymskim zniesławienie jako osobna instytucja prawna nie występowało.

Treść książki zawiera wiele innych jeszcze szczegółowych zagadnień i analiz, które nie mogą być tu szczegółowo zrelacjonowane (np. ciekawa iniuria wobec właściciela dokonana pośrednio przez zniesławienie niewolnika - s. 231-238). Całość ułożona jest ponadto w dwu warstwach. Pierwszą stanowią rozważania w głównym tekście, drugą przypisy. Autorka z wyraźną biegłością i znajomością rzeczy prowadzi swój dyskurs w obrębie kolejnych kwestii, ułożonych i zaznaczonych w spisie treści i należy przyznać, że lektura jest tutaj interesująca oraz merytorycznie uzasadniona przyjętymi założeniami badawczymi. Znajdują się tu analizy tekstów źródłowych, wątki dyskusyjne, jasno wyrażone poglądy Autorki oraz podsumowania. Ten główny nurt uzupełniają przypisy, postawione na wyjątkowo wysokim poziomie. Wbrew dość powszechnej praktyce stanowią one nie tylko schematyczne wskazówki co do literatury i uzupełniających źródeł, ale zawierają przede wszystkim staranne i wnikliwe analizy literatury tematu i wątków ubocznych, do których Autorka odnosi się merytorycznie. W rezultacie przypisy, stanowiące dość znaczną część książki, tworzą wartościową bardzo i spójną z całością warstwę merytoryczną monografii, zasługującą na duże uznanie.

Gdyby podnieść pewne zastrzeżenia, to pomijając niektóre niezręczności (np. dwuznaczny i nienajlepiej się kojarzący „,społeczny wymiar sprawiedliwości” - s. 55; 57; 58-59), zwróciłbym przede wszystkim uwagę na zasadnicze pominięcie aspektu dobrych obyczajów (boni mores). Wyraźne są one w rozdziale II, gdzie karalność omówionych przez D. Nowicką na pierwszym miejscu działań Adversus bonos mores convicium facere oraz Adversus contra bonos mores appelare jednoznacznie znajduje uzasadnienie w naruszeniu właśnie dobrych obyczajów, a w każdym razie jest ono ważną przesłanką oceny represyjności takiego zachowania. Autorka, jak już zauważono, nie gubi całkiem tego elementu, ale powinna moim zdaniem poświęcić mu znacznie więcej uwagi w kontekście zachowań nie tylko contra leges, 
ale właśnie contra bonos mores. Dostrzegłaby może wówczas jednak związki m. in. ze stuprum (s. 70) i pudor (s. 144) oraz w ogólności doniosłą rolę, jaką w ocenie zachowań naruszających dobre imię odgrywały dobre obyczaje, stanowiące dla Rzymian jedną z głównych podstaw porządku społecznego i prawnego. Na zmianę monografii już za późno, ale zachęcałbym Autorkę do przyjrzenia się temu wątkowi w osobnym może opracowaniu.

Od strony technicznej postulowałbym dodawanie przekładu polskiego do powoływanych in extenso źródeł łacińskich i greckich Książka już swoim tytułem może zwrócić uwagę dzisiejszych czytelników, zainteresowanych problematyką zniesławienia, ale teksty łacińskie i tym bardziej greckie, pozostawione bez przekładu, prowadzą zwykle do zniechęcenia, kto bowiem dzisiaj - poza specjalistami - miałby wystarczające umiejętności i cierpliwość w studiowaniu łaciny i greki. A skoro mowa o dzisiejszych czytelnikach, to powrócę jeszcze do aspektów współczesnych. Wbrew zapowiedzi są one obecne w monografii, czego dowodem jest choćby wykaz aktów normatywnych polskiego prawa karnego (s. 309). Pominięty w nim został jednak art. 216 k.k. o znieważeniu, chociaż w literaturze prawa karnego przyjmuje się, że zniewaga to ubliżenie komuś najczęściej właśnie słowem (użycie słów wulgarnych, epitetów) lub pismem (np. list o obraźliwej treści) czy rysunkiem (np. karykatura), co w znacznej mierze odpowiada przyjętej przez Autorkę koncepcji rzymskiego zniesławienia. Gdy zaś mowa o sferze czci osoby prywatnej (s. 15) i jej dobrach osobistych (np. s. 293), to nasuwa się - obok prawa karnego - kodeks cywilny z art. 23 i 24. Wśród wyliczonych w art. 23 k.c. chronionych dóbr osoby fizycznej z łatwością znalazłaby Autorka możliwe odniesienia do prawa rzymskiego. Wyliczenie nie jest zresztą wyczerpujące, mieści się w nich także. np. ochrona pamięci o zmarłym, jego pogrzebu i grobowca (por. s. 17 omawianej książki). Nie namawiam do szukania na siłę i zestawiania prawa rzymskiego z polskim, ale nad programowym odcinaniem się od takich porównań należałoby się jednak zawsze dokładniej zastanowić.

Kończy Autorka swoje rozważania m. in. stwierdzeniem o potrzebie kontynuowania studiów nad poruszoną w książce problematyką. To 
właściwe podejście badawcze. Uznanie swojej rozprawy za otwarcie tematyki badawczej bez przypisywania sobie sukcesu wyczerpania jej i zamknięcia, dobrze świadczy o kwalifikacjach naukowych pani Dobromiły Nowickiej.

Marek Kuryłowicz*

* Akademia Leona Koźmińskiego w Warszawie 